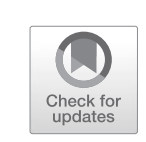

\title{
2.26 Kaufleuten (Theatre)
}

Like the Pfauen (1888/89), the Kaufleuten was built to serve the needs of a rapidly growing city. Originally called Vereinshaus Zur Kaufleuten, the complex was constructed in two stages, from 1909 to 1915 and from 1927 to 1929, as the headquarters of the Zurich Mercantile Association. In addition to offices and schoolrooms it also contained shops, a restaurant and a theatre-cum-ballroom. Completed in 1915, the Kaufleuten theatre was fairly new when the English Players started operating in 1918. Their first production, Wilde's The Importance of Being Earnest, premièred at the Kaufleuten on 29 April 1918, their second one at the Pfauen. For their subsequent productions the English Players used the Kaufleuten (September 1918 to March 1919) as well as the Pfauen (April to December 1919). ${ }^{1}$ The Kaufleuten was also the venue of the eighth and last official Dada soirée in Zurich, which took place on 9 April 1919. ${ }^{2}$

While the Pfauen stage eventually became the home of the city's playhouse (Schauspielhaus), the Kaufleuten remained in private hands. It was sold in 1992, but the restaurant, a club and the stage are still popular venues. The stage is used for a range of cultural events such as readings, panel discussions and concerts.

\section{Notes}

1. See the article on the English Players for details.

2. Schrott, Dada 15/25, 205-209.

(C) The Author(s), under exclusive license to Springer Nature 161 Switzerland AG 2020

A. Fischer, James Joyce in Zurich, https://doi.org/10.1007/978-3-030-51283-5_30 